\title{
Climate Conditions Impact on the Sap Flow Into Plants and Their Dendrometric Changes
}

\author{
Anna Báreková', Viliam Bárek², Martina Kováčová2 ${ }^{*}$, Beáta Novotná2 ${ }^{2}$ Vladimír Kišš³ \\ 1 Department of Landscape Planning and Land Consolidation, Faculty of Horticulture and Landscape \\ Engineering, Slovak University of Agriculture in Nitra, Slovakia \\ 2 Department of Water Resources and Environmental Engineering, Faculty of Horticulture and Landscape \\ Engineering, Slovak University of Agriculture in Nitra, Slovakia \\ 3 Department of Biometeorology and Hydrology, Faculty of Horticulture and Landscape Engineering, Slovak \\ University of Agriculture in Nitra, Slovakia \\ *Corresponding author's e-mail: m.tinkakovacova@gmail.com
}

\begin{abstract}
Water stress is an indicator that plant are suffering from drought. For optimization of the crop production is necessary to indicate physiological changes, those can be represented by stem expansion or shrinkage and sap flow rate. We used the Dynagage SGA5-WS (Dynamax) sensors for the sap flow monitoring and the sensors Diameter Dendrometer Small (Ecomatik) for measuring branches diameter changes in our research. The research was realized during two seasons, in the summer (from $31^{\text {st }}$ July to $14^{\text {th }}$ August 2018) and in the spring (from $27^{\text {th }}$ March to $14^{\text {th }}$ April 2019). The subject in our research were walnut trees (Juglans regia) situated in the private orchard in Nové Zámky area in Slovak Republic. The sap flow values in summer were on average range of $90 \mathrm{~g} \cdot \mathrm{h}^{-1}$, with maximum measured values above $160 \mathrm{~g} \cdot \mathrm{h}^{-1}$ measured after the precipitation events. After increasing of soil moisture on $1^{\text {st }}$ and $2^{\text {nd }}$ August 2018, it was detected the branches diameter expansion up to $0.05 \mathrm{~mm}$. However, the other spring values were much lower. The sap flow reached less than $35 \mathrm{~g} \cdot \mathrm{h}^{-1}$ what was one third values in summer 2018. This phenomenon is a result of the low transpiration intensity of transpiration or a leafless state of trees. Although the changes in diameter were not significant in the early vegetation stage, there were monitored some fluctuation causing the diameter was shrinked by $0.2 \mathrm{~mm}$ due to a negative average air temperature.
\end{abstract}

Keywords: sap flow, dendrometer, drought

\section{INTRODUCTION}

In the present time the global climate change is one of the most serious global problems. In past years the impact of climate warming was expressed as the drought events, those can be characterized by the single events or long drought periods with resulting in considerable financial damage. In the demand of the agricultural water consumption a significant increase is expected in following years because of the global population growth, and the economic development to the latest climate change scenarios. The improvement of the irrigation water management is crucial to increase water use efficiency and enhance the sustainability of irrigation agriculture consequently [Vogt, 2018]. The main purpose of the agricultural irrigation is the water supply for the plants with considering the economic and ecological water resources efficiency. This is making possible to fulfil with a proper detection method specifying the water deficit time of the plants.

\section{Sap flow measurement}

The sap flow and transpiration are key indicators reflecting the tree water status. These processes play a key issue in the plant drought research. The transpiration and the sap flow are 
the main indicators determined the plant's water status. There are a variety of methods for calculation of mass flow of water in the transpiration steam by using heat as s tracer. The sensors can be placed into the roots and into other conductive organs of the plants. Fernández (2017) described the Vieweg's and Ziegler's (1960) method where a heater band was wrapper around the conductive organs. This heater band constantly applied in a small amount of heat increase the intact stem temperature into the place around the sensor to keep temperature higher than the non-heated parts.

The stem heat balance method that uses a constant power input to the heater is manufactured by Dynamax Inc., Houston Texas. A strip heater within the gauge inputs the energy to the stem at a constant rate (Qin). The energy balance is based on the principle that the conservation of energy determines the partitioning of energy into the stem as the heat flux energy (Qf) and the sap flow (Qf), whereas including the heat losses to the ambient:

$$
\mathrm{Qin}=\mathrm{Qf}+\mathrm{Qv}+\mathrm{Qr}+\mathrm{Qs}
$$

where: Qin is the constant heat applied in Watts, $Q f$ is the heat flux energy carried by the sap flow,

$Q V$ is the heat conducted up (qu) and down (qd) to the stem axially,

Qr is the heat conducted through the insulation radially to the stem test section. For the most applications Qs is assumed to be small and can be ignored for all but very low sap flow applications. The values Qin, Qd, Qu, Qr were obtained by the measurements and Qf was calculated if possible. After dividing the heat capacity on the water and the temperature increase, the heat flux was converted directly to mass flow rate [Van Bavel, 1993].

\section{Dendrometric measurement}

Changes in stem size have been associated with tree water status for many years. For measuring the trees diameters were used to apply the dendrometers. The daily fluctuations in stem size were related to the parameters such as leaf water potential and vapor requirement. These stem radius changes consisted of the actual radial growth, shrinkage and swelling from the inflow and outflow of the water [Drew, Downes, 2009].

\section{MATERIAL AND METHODS}

\section{Study area}

The region of Nové Zámky is situated in the middle part of Podunajská Lowland, which is the biggest lowland in Slovakia located in southwestern part of the Pannonian Basin. Our study area, the walnut trees orchard, is located at the eastern part of the city in the agricultural area. Nové Zámky region is situated in the southwestern part of Slovakia, the climate conditions are very warm and very dry with mild winter with temperature in the January less than $-2{ }^{\circ} \mathrm{C}$. During the year the average annual air temperature is $10^{\circ} \mathrm{C}$, in July is average air temperature more than $20^{\circ} \mathrm{C}$. Annual rainfall is $500-550 \mathrm{~mm}$. The snow cover is less than 40 days in course of the year. The climate indicators of irrigation is $>200 \mathrm{~mm}$, what means the deficit of the soil moisture [Atlas krajiny SR, 2002]. The relief territory has a not dissected plain structure. In this area the geological structure is Neogene, which contains gray and variegated clays, silts, sand and glaves. Soil types are Mollic Fluvisols and Mollic Gleysols mainly from non - carbonate alluvial sediments, medium heavy to light soils with good water regime.

\section{Diameter measurements}

Stem radius was measured by Dimeter Dendrometer small (DD-S), which obtain the exact values of the vertical and radial changes in the texture of the plant by continual monitoring. The DD-S is suitable for plants with diameter less than $50 \mathrm{~mm}$. It is designed specifically for application on agricultural plants and trees, but it makes also possible to provide the stable monitoring on very small plants. Especially it is suitable for measurements of young plant parts [Ecomatic, 1999].

In our study it was used the Datalogger DL18 with precision of measurement $\pm 0.1 \%$, what is the standard accuracy for dendrometers up to $2 \mu \mathrm{m}$. The output signal of the datalogger is in the range from 0 to $11000 \mathrm{ohms}$. Datalogger does not need to be connected to any external source, it is possible use the batteries or solar panels. Datalogger can be installed in the exteriors with a temperature range from -30 to $+40{ }^{\circ} \mathrm{C}$ with a relative air moisture from 0 to $40 \%$. The sensors are made from a durable material as are the rustles steel or aluminium. The weight of the sensors is $13 \mathrm{~g}$, therefore its installation on the plant it does 
not cause any damage in the plant texture. The standard length of the cable is $5 \mathrm{~m}$ with possibility of prolongation up to $100 \mathrm{~m}$ [Kaletová, 2019; Ecomatic, 1999].

\section{Sap flow measurements}

The stem heating balance method requires a steady state and a constant energy input from the heater strip inside the plant body. Thus, the stem section has to be insulated from external changes in the environment. For the same reason, the time interval is limited from five minutes to an hour, depending on the flow rate and the stem size. The Dynamax loggers have a power down mode what allows to save the energy during the night and at the same time the stem is preserved from overheating [Smith, Allen, 1996]. When using the power down mode and the transitions to power on, the sap flow is not computed however it maintains the accumulated flow accurately during this unbalanced transition. The theory of the stem flow gauges is based on the principles of conservation of energy and mass, where all inputs and outputs are considered. Therefore, it works by applying a known amount of heat to the small segment of the stem from a thin flexible heater surrounding the stem and it is itself encircled by the foam insulation [Lascano et al. 2016; Kišš, Manina, 2019]. In general, this is known as the Stem Heat Balance method. In steady state, the heat input from the heater is balanced by the heat fluxes out of the stem according to the formula:

$$
F=\frac{(\mathrm{Pin}-\mathrm{Qv}-\mathrm{Qr})}{\mathrm{Cp} * \mathrm{dT}}\left[\mathrm{g} \cdot \mathrm{s}^{-1}\right]
$$

where: $F$ is sap flow $\left(\mathrm{g} \cdot \mathrm{s}^{-1}\right)$,
Pin is the power of heater (W),

$Q v$ is vertical conduction,

$Q r$ is radial conduction,

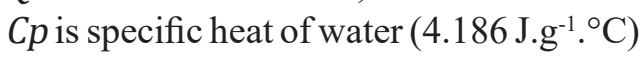
and $d T$ is temperature increase of sap $\left({ }^{\circ} \mathrm{C}\right)$

[Dynamax Inc., 2007].

\section{RESULTS AND DISCUSSION}

Our measurements were taken in two periods from $31^{\text {st }}$ July to $14^{\text {th }}$ August 2018 and from $27^{\text {th }}$ March to $14^{\text {th }}$ April 2019. The aim of our research was compared sap flow and dendrometric changes in two seasons (summer and spring). It is well known that walnut trees (Juglans regia) have the biggest water demand in time of the full foliage and intense fruit growth. As we mention above, the method of measuring sap flow can be described as a function between the air temperature, precipitation and soil moisture. The mutual values changes in whole measured periods are presented in Figure 2 and Figure 3.

Depending on the measurements, during the day diameter and sap flow were changing constantly. These changes can be described as reaction of the tree to waters stress. At the beginning of the first period there were recorded a significant increase of the sap flow and the dendrometric changes. During the period from $31^{\text {st }} \mathrm{July}$ to $02^{\text {nd }}$ August 2018 were measured the precipitation income which had an impact to the tree's growth and the sap flow. In this vegetation stage, the walnut tree, most of the water consumption was transported to their leaves and fruits. The highest measured value of sap flow was 164,26 g.h $\mathrm{h}^{-1}$

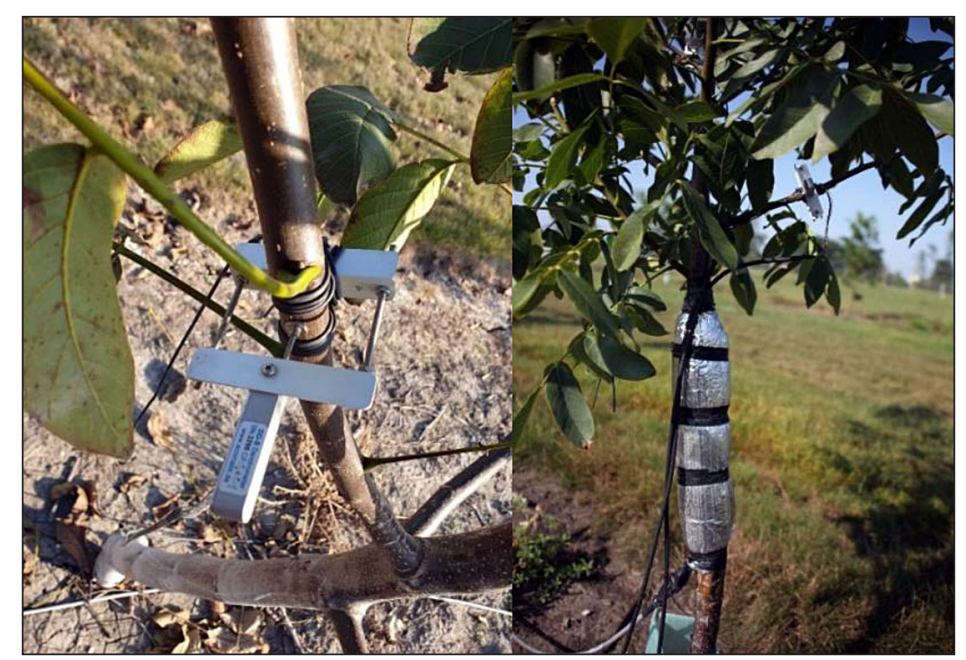

Fig. 1 Dendrometer diameter small (Ecomatik) and Dynagage sap flow sensor (Dynamax) 


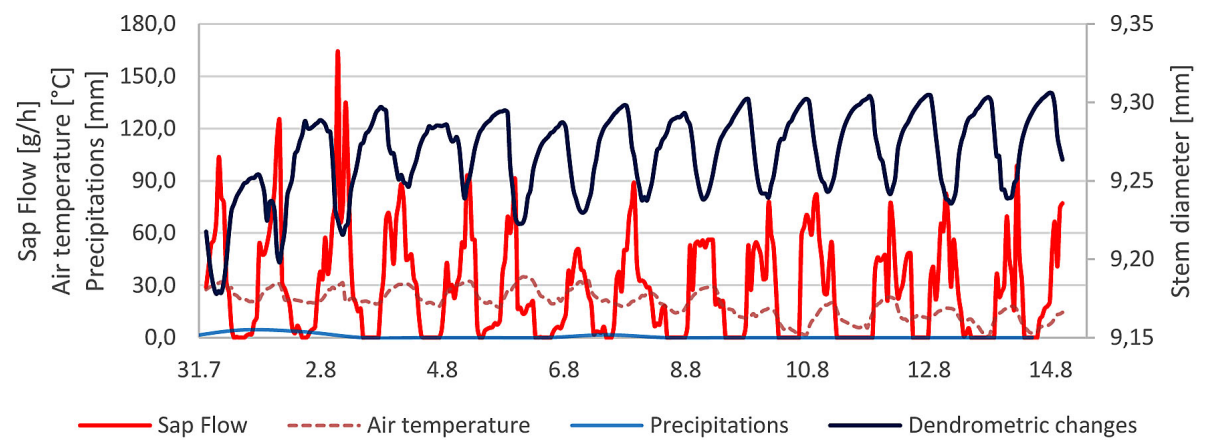

Fig. 2 Comparison of the sap flow and the dendrometric changes with precipitation (31 $1^{\text {st }}$ July $-14^{\text {th }}$ August 2018)

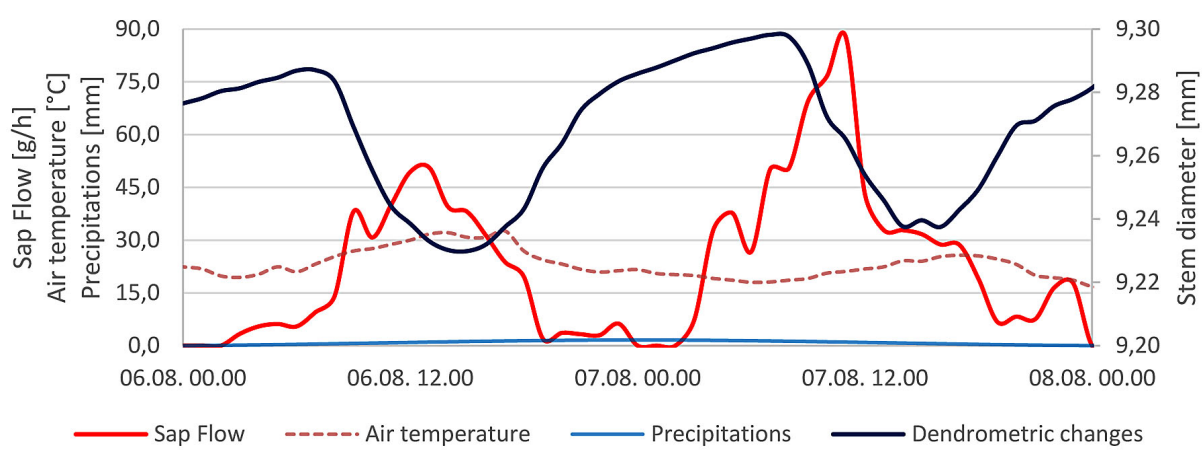

Fig. 3 Comparison of sap flow and dendrometric changes with temperature and precipitation in 2-days interval $\left(06^{\text {th }}\right.$ August $-08^{\text {th }}$ August 2018)

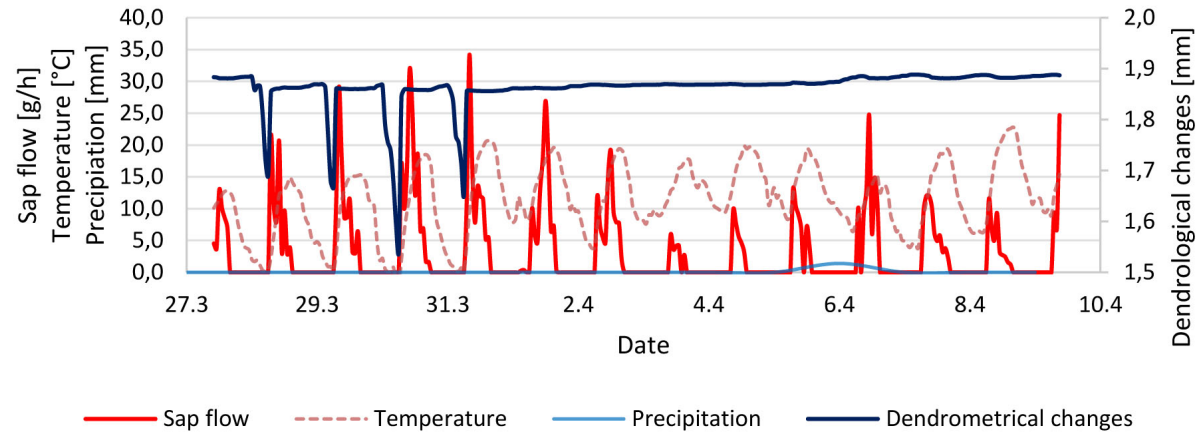

Fig. 4 Comparison of sap flow and dendrometric changes with temperature and precipitation $\left(27^{\text {th }}\right.$ March $-10^{\text {th }}$ April 2019)

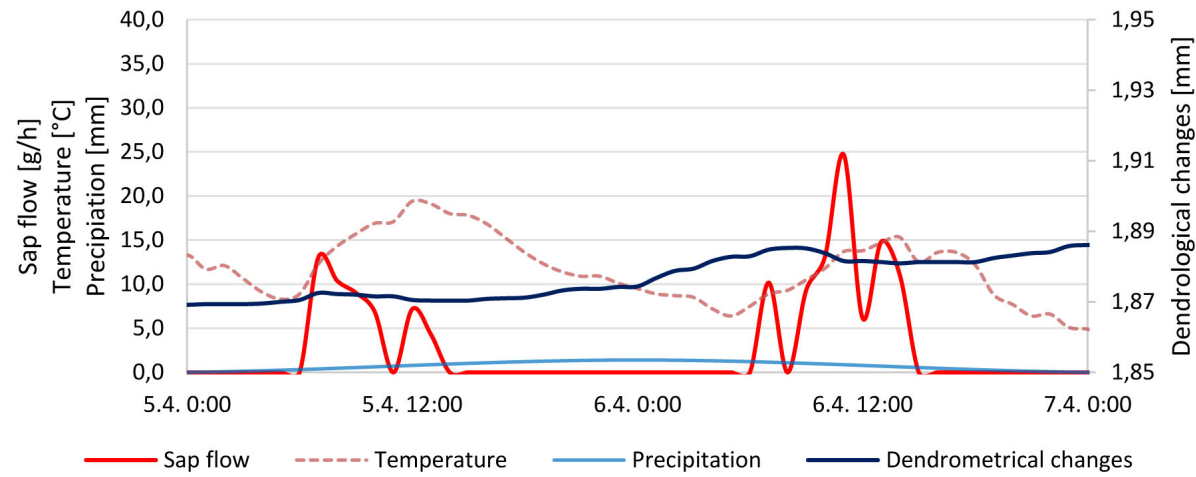

Fig. 5 Comparison of sap flow and dendrometric changes with temperature and precipitation in 2-days interval $\left(05^{\text {th }}\right.$ April $-07^{\text {th }}$ April 2019) 
on $02^{\text {nd }}$ August 2019. Changes in diameter from the start of monitoring was from value 9,17 to $9,30 \mathrm{~mm}$. During the stable precipitation conditions, the difference in diameter values was about $0,05 \mathrm{~mm}$. In the rest of the precipitation period were not any significant impact and on the sap flow and it had mostly the same values depending on the part of the day.

Detail analyses of the data measured in summer period show that the changes in individual variables are more noticeable. Diameter of the stems were growing because transpiration of water was also decreasing, however the water storage in tree was increasing. The consequence of this process is gradual increase into the sap flow. Both the diameter and sap flow started decreasing with higher temperatures.

Figure 4 represents data at the beginning vegetation period. The significant dentrometric changes in days with differences between day and night temperatures were more extreme at the beginning of the spring measurements. The diametric changes range has the maximum value $1,88 \mathrm{~mm}$. After the temperature increase during the night above $0,0{ }^{\circ} \mathrm{C}$, there were not recorded the substantial difference in stem diameter. The sap flow values vary from 0 (as consequence of low temperature) to $34,1 \mathrm{~g} \cdot \mathrm{h}^{-1}$.

Comparing spring and summer values, the diameter changes and sap flow have lower values in summer period. The more significant role played the temperature than the precipitation. When the temperature decreases less than $0,0{ }^{\circ} \mathrm{C}$ the soil water was frozen and access of the roots to water was limited by their movement.

\section{CONCLUSION}

In our research we observed that the higher amounts of the sap flow and dendrometric values were recorded in the different day time. During the time when the day temperature was on its maximum value, the sap flow level value was also on its maximum value in comparison with dendrometric changes; their values were on the lower rate. The sap flow values were on average range of $90 \mathrm{~g} \cdot \mathrm{h}^{-1}$, with maximum measured values above $160 \mathrm{~g} \cdot \mathrm{h}^{-1}$ as a result of the precipitation event. After water income in $1^{\text {st }}$ and $2^{\text {nd }}$ August 2019, it was recorded an increase of branches diameter about $0,05 \mathrm{~mm}$. The spring sap flow values were much lower. The sap flow reached less than $35 \mathrm{~g} \cdot \mathrm{h}^{-1}$ what was one third of the summer values in the year 2018. This phenomenon was due to a lower intensity of transpiration or without the leaves stage of trees. Changes in diameter were not significant due early the vegetation stage. As we can see the relation between the temperature and the dendrometric changes, there was an opposite situation in the sap flow and the temperature case. This relation we observed during the both periods of our research.

\section{Acknowledgements}

This study was supported by APVV project under the contract No. APVV- 15-0562 and KEGA project under the contract No. KEGA- 047SPU-4/2017.

\section{REFERENCES}

1. Atlas krajiny Slovenskej republiky. 2002. Bratislava: Ministerstvo životného prostredia SR a Banská Bystrica: Slovenská agentúra životného prostredia, 344 s. (in Slovak).

2. Drew D.M., Downes G. M. 2009. The use of precision dendrometers in research on daily stem size and wood property variation: A review. Dendrochronologia 27 (2009) 159-172.

3. Dynamax Inc. 2007. Flow32-1K Sap Flow Monitoring System Installation \& Operation Manual, USA, p 40.

4. Ecomatic. 1999. User manual, pp 45-51.

5. Fernández E. et al. 2017. Methods to Estimate Sap Flow. ISHS Working Group on Sap Flow, pp. 1-9.

6. Kaletová T. et al., 2019. Kurz monitoringu zložiek životného prostredia. Nitra: SPU, 86 s. (in Slovak).

7. Papi D., Storchi P. 2012. Dendrometric measurements and water potential analysis on Sangiovese grapevine. Acta horticulturae 951(951):161-165.

8. Smith D.M., Allen S.J. 1996. Measurement of sap flow in plant stems. Journal of Experimental Botany, Vol. 47, No. 305, pp. 1833-1844.

9. Van Bavel M. G. 1993. System Solution for RealTime Sap Flow Monitoring. International Water \& Irrigation Review, Vol. 13, No. 1, pp.25-29.

10. Vogt, J.V., et al. 2018. Drought Risk Assessment. A conceptual Framework. EUR 29464 EN, Publications Office of the European Union, Luxembourg. DOI:10.2760/057223, JRC113937.

11. Kišš V., Manina M. 2019. Effect of SAP FLOW at optimization irrigation. SGEM 2019, Sofia: STEP92 Technology, p. 161-168.

12. Lascano R.J. et al., 2016. The Stem Heat Balance Method to Measure Transpiration: Evaluation of a New Sensor. Journal of Agriculture science, Vol 07, No. 09, 604-620. DOI:10.4236/as.2016.79057 